стратиграф. конф., Саратов, 6 - 9 дек. 2004 г. Саратов, 2004. C. 94-95.

11. Салтыков В.Ф. Фораминиферовые зоны келловейского яруса в Нижнем Поволжье // ДАН. 2006. Т. 407, № 3. C. $367-371$.

12 Атлас текстур и структур осадочных горных пород: В 3 ч. Ч. 2. Карбонатные породы / Ред. А.В.Хабаков. М., 1969. $707 \mathrm{c}$.

13. Пименов М.В., Гужиков А.Ю., Салтыков В.Ф. Выделение реперных корреляционных уровней по геохимическим данным для стратификации среднеюрских отложений на севере Доно-Медведицких дислокаций // Юрская система России: проблемы стратиграфии и палеогеографии: Материалы Первого Всерос. совещ. М., 2005. С. 193-194.

14. Гаврилов Ю.О. О диагенетическом ритмообразова- нии // Литология и полезные ископаемые. 1979. № 4. C. $132-143$.

15. Страхов Н.М. Основы теории литогенеза: В 3 ч. T. 2. Закономерности состава и размещения гумидных отложений. М., 1962. 574 с.

16. Колокольцев В.Г. Текстура cone-in-cone и ее происхождение // Литология и полезные ископаемые. 2002. № 6. C. 612-627.

17. Тимофеева 3.В. Сидеритоносность мелководноморских и дельтовых отложений и факторы ее определяющие // Дельтовые и мелководно-морские отложения. М., 1963. С. 174-179.

18. Ветошкина О.С. Сидеритовые биоморфазы в юрских отложениях Нижневычегодской впадины севера Русской плиты // ДАН. 2006. Т. 406, № 5. С. 663-667.

УДК 553.632 (470.45)

\title{
УСЛОВИЯ ФОРМИРОВАНИЯ ГАЛОГЕННЫХ ПОРОД РАЙОНА ГРЕМЯЧИНСКОГО МЕСТОРОЖДЕНИЯ СИЛЬВИНИТОВ
}

\section{Г.А.Московский, С.А.Свидзинский ${ }^{1}$, А.И.Петрик ${ }^{1}$}

Саратовский государственный университет, кафедра мениралогии и петрографии E-mail: MoskovskyGA@info.sgu.ru

${ }^{1}$ ОАО «ЕвроХим-ВолгаКалий»

E-mail: lavanda741@yandex.ru

Гремячинское месторождение сильвинитов располагается на юге Приволжской моноклинали, к северо-востоку от СевероКотельниковского надвига. Исследовались галогенные отложения месторождения. Выполненные работы позволили обосновать, что калиеносный горизонт месторождения сопоставляется с погожской ритмопачкой Приволжской моноклинали. Формирование галогенных отложений происходило под влиянием основной акватории солеродного бассейна, располагавшегося на востоке, и с заметной ролью хлоркальциевых вод, разгружавшихся по разрывным нарушениям, ограничивавшим зону надвига. В средней части галогенного разреза велико влияние постседиментационных деформаций в соленосных интервалах разреза. На месторождении развиты три разновидности сильвинитов: а) красный, оранжевый и пестрый; б) молочно-белый и розовый; в) молочно-белый шпатовый, перекристаллизованный. Красный сильвин в большинстве случаев кристаллизовался из рапы растворения карналлита. Особенностью строения сильвинитов здесь является отсутствие типичных седиментационных сезонных ритмов.

Environment of Halogen Rock Formation in the Region of the Gremyachinskoye Sylvinite Field

\section{G.A. Moskovskij, S.A. Svidzinskij, A.I. Petrik}

The Gremyachinskoye sylvinite field lies in the south of the Volga monocline, to the northeast of the Severo-Kotelnikovskij overthrust. Halogen beds from the field were examined. The study has provided grounds for correlating the field potassium-bearing horizon with the Pogozhskaya rhythmic member from the Volga monocline. The halogen bed formation was influenced by the principal water area of the salt-generating basin in the east and by the calcium chloride brines discharged along the disjunctive dislocations limiting the overthrust zone. The middle part of the halogen section is greatly affected by the post-sedimentation deformations in the salt-bearing section intervals. Three sylvinite varieties occur in the field: a) red, orange and mottled; b) milk-white and pink; c) milk-white spathic, recrystallized. Red sylvite was mostly crystallized from carnallite dissolution brine. The sylvinite structure there is peculiar for the lack of typical sedimentation seasonal rhythms.

Гремячинское месторождение располагается в 208 км юго-западнее г. Волгограда в так называемый преднадвиговой зоне, условно выделяемой в южном окончании Приволжской моноклинали, к северо-востоку от Северо-Котельниковского надвига (рис. 1). Интерпретация каротажных материалов по пробуренным здесь ранее скважинам нефтяных организаций позволила геологам Волгоградской ГРЭ на стадии детальных поисков (когда было пробурено 6 скважин) установить в разрезе соленосной толщи сильвинитовую залежь промышленной мощности [1]. В данной статье учтены результаты ранее выполненных работ по скв. 2-7 (1979-1982 гг.), а также материалы, полученные по скв. 8, 10 и 13, пробуренным на месторождении ООО «ЕвроХим-ВолгаКалий» в 2006-2007 годах.

Ритмостратиграфия галогенного разреза Гремячинского месторождения. Близость месторождения к краевой части солеродного бассейна, весьма сложная морфология его дна обусловили сокращенную мощность хлоридной части разреза и выпадение его отдельных элементов как в кровле, так и подошве галогенной толщи, замещение части хлоридных элементов разреза сульфатно-карбонатными. Для вскрытой части 


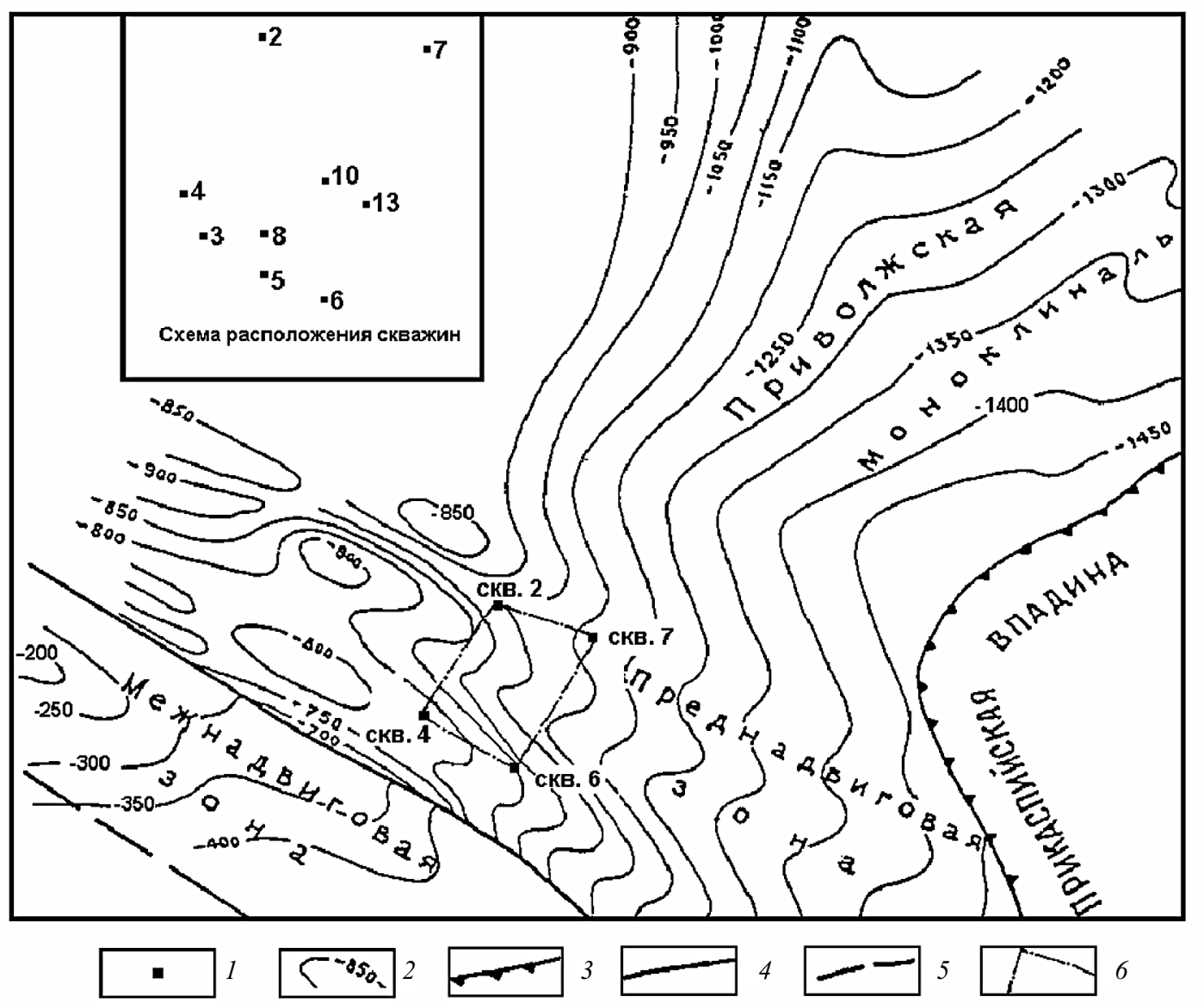

Рис. 1. Схема расположения месторождения: 1 - скважины; 2 - изолинии кровли галогенных отложений; 3 - бортовой уступ Прикаспийской впадины; 4 - разрывные нарушения установленные; 5 - разрывные нарушения предполагаемые; 6 - границы участка

разреза это отразилось в значительном усложнении строения его верхней части, что произошло за счет увеличения количества и мощностей терригенно-сульфатных и сульфатно-карбонатных прослоев, а также существенных постседиментационных деформаций. Деформации проявились весьма избирательно - на заключительных стадиях литификации пород, в отложениях средней части галогенного разреза. Деформации привели к будинированию ангидритовых слойков и пачек, с частичным перераспределением галита, его «затеканием» в межбудинные пространства. Однако первичная «перистая» структура кристаллов галита сохранилась на значительных интервалах надпродуктивной части галогенного разреза.

С.А.Свидзинским и др. [1] в разрезе месторождения (главным образом по скв. 2) были выделены все верхние (начиная с погожской) ритмопачки сводного разреза галогенных отложений моноклинали (снизу-вверх): погожская, антиповская, пигаревская, долинная и ерусланская. Однако при таком варианте расчленения пигаревская и долинная ритмопачки представлены лишь доломит-ангидритовыми породами (иногда ангидритом с несущественной примесью галита). В скважинах южной части участка месторождения однозначно выделяются лишь калийно-магниевые и калийные породы нижней - «продуктивной» погожской ритмопачки.

«Продуктивная» римопачка месторождения определяется как погожская на основании ряда фактов: по увеличению содержаний магния в растворах включений в седиментационном галите основания продуктивной толщи в направлении восточной части участка, по соответствию состава растворов включений в эвтоническом галите из карналлит-галитовых пород скв. 6 бишофитовой стадии сгущения, по относительно незначительной мощности отложений стадии опреснения. К такому же выводу приводит анализ закономерностей эволюции галогенного разреза моноклинали, что выражается в выпадении из него, в южном и западном направлении, как верхних, так и нижних элементов разреза и переход циклов в категорию редуцированных или неполных. Таким образом, единственным элементом разреза, представленным во всех пробуренных здесь скважинах, является залегающая в подошве кунгурских отложений ритмопачка, сложенная «продуктивным» горизонтом, подстилаемым сульфатными породами подготовительной стадии и первой галитовой зоной. «Продуктивный» горизонт 
перекрывается доломит-ангидритовыми породами стадии опреснения (рис. 2). В галогенной толще, перекрывающей калиеносную ритмопачку, можно выделить две галитовые зоны, разделяемые отложениями подготовительной стадии. Более детальное расчленение галогенного разреза пока затруднительно.

Палеогидрохимические условия седиментации и диагенеза галогенных отложений Гремячинского месторождения калийных солей. Анализ реликтов седиментационной рапы в галите из основания хлоридной части разреза скв. 2 показал (табл. 1, рис. 1), что рапа данного участка солеродного бассейна была сульфатной, сгущенной почти до эпсомитовой стадии $\left(\mathrm{K}^{+}-20-25, \mathrm{Mg}^{2+}-35-50, \mathrm{SO}_{4}^{2-}-8-10\right.$ г/л). Это позволяет говорить о том, что галогенез в районе месторождения начинался при поступлении уже сгущенной рапы из западной части впадины. Лишь затем начинался дальнейший рост ее концентрации. На глубине 1240 м по скважине, судя по анализам состава включений, породы кристаллизовались уже из рапы карналлитовой стадии. Этому соответствует появление вкрапленности карналлита и сильвина в каменной соли. В то же время значительная часть галитовой зоны в разрезах скв. 2-5 перекристаллизована. Судя по составу растворов включений в диагенетическом галите $\left(\mathrm{K}^{+}-5-10, \mathrm{Mg}^{2+}-25-40, \mathrm{Ca}^{2+}-10-30\right.$ г/л), это происходило при участии опресненных, относительно седиментационной рапы, растворов хлоркальциевого состава (табл. 2).

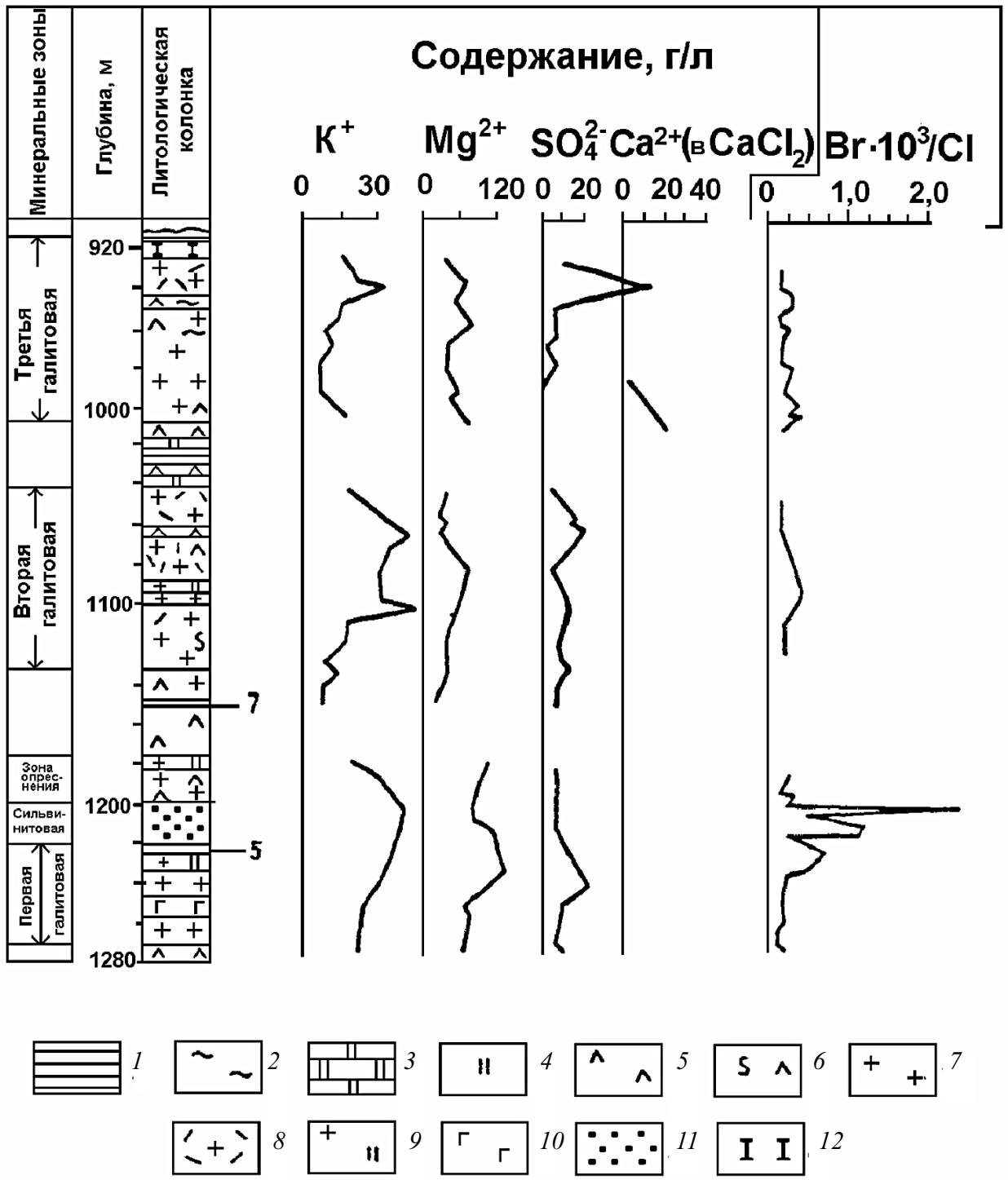

Рис. 2. Ритмостратиграфическая колонка, закономерности распределения состава растворов включений в седиментационном галите и величин бромхлорного отношения в породах скв. Сафроновской 2: 1 - глина; 2 - примесь пелитового материала в соли; 3 - доломит; 4 - вкрапленность карналлита; 5 - ангидрит; 6 - интенсивная дислоцированность ангидритовых слойков; 7 - каменная соль; 8 - каменная соль «перистая»; 9 - каменная соль с вкрапленностью карналлита; 10 - галитит; 11 - сильвинит; 12 - интервал замещения калийных солей галититом 
Таблица 1

Средние содержания калия, магния, сульфата и кальция в рапе включений седиментационного галита, молочнобелого и красного сильвина Гремячинского месторождения калийных солей

\begin{tabular}{|c|c|c|c|c|c|c|}
\hline \multirow{2}{*}{ № скв. } & \multirow{2}{*}{ Глубина, м } & \multicolumn{4}{|c|}{ Средние содержания, г/л } & \multirow{2}{*}{ Примечания } \\
\hline & & $\mathrm{K}^{+}$ & $\mathrm{Mg}^{2+}$ & $\mathrm{SO}_{4}^{2-}$ & $\mathrm{Ca}^{2+}$ & \\
\hline 2 & 919,8 & 21,87 & 78,3 & 9,31 & Не обнаружено & - \\
\hline 2 & 934 & 30,75 & 73,3 & 49,6 & То же & - \\
\hline 2 & 963,9 & 8,79 & 33,63 & Следы & То же & - \\
\hline 2 & 973,8 & 6,15 & 30,8 & Не обнаружено & 4,2 & - \\
\hline 2 & 990 & 6,51 & 32,68 & То же & 8,0 & - \\
\hline 2 & 1006,7 & 16,4 & 63,7 & - & 17,5 & - \\
\hline 6 & 1033,5 & 0,5 & 105 & 1,0 & не обн. & - \\
\hline 6 & 1039,5 & 20,1 & 98,2 & Следы & То же & - \\
\hline 6 & 1043 & 19.5 & 100,4 & 8,5 & То же & - \\
\hline 4 & 1046,8 & 32,2 & 83,4 & 10,25 & То же & - \\
\hline 6 & 1052 & 16.1 & 102,3 & 6,8 & То же & - \\
\hline 3 & 1058,4 & 31,34 & 82,7 & 6,2 & То же & - \\
\hline 6 & 1060,5 & 29.5 & 72,28 & 7,13 & То же & - \\
\hline 2 & 1061,5 & 47,7 & 27,16 & 23,8 & То же & Рапа растворения \\
\hline 6 & 1072,3 & 32 & 78,5 & Не обнаружено & То же & - \\
\hline 2 & 1073,7 & 26,81 & 106,51 & Следы & То же & - \\
\hline 3 & 1075,9 & 19,6 & 98,7 & 22 & То же & - \\
\hline 3 & 1084,7 & 28,0 & 69,7 & Не обнаружено & То же & - \\
\hline 2 & 1085,1 & 27,2 & 64,67 & 8,29 & То же & - \\
\hline 6 & 1096,0 & 26,0 & 64,5 & Не обнаружено & Не обнаружено & - \\
\hline 2 & 1098 & 30,9 & 60,8 & 10,8 & То же & - \\
\hline 2 & 1132 & 15,23 & 33,16 & 15,58 & То же & - \\
\hline 2 & 1148,5 & 6,17 & 17,75 & 7,6 & То же & - \\
\hline 7 & 1150 & 19,5 & 100,2 & 16,2 & То же & - \\
\hline 2 & 1176,8 & 15,51 & 104,6 & 6,6 & То же & - \\
\hline 13 & 1179 & 37,57 & 89,3 & Следы & 6,5 & - \\
\hline 10 & 1185,3 & 32,8 & 91,0 & Не обнаружено & Не обнаружено & - \\
\hline 2 & 1197,9 & 49,08 & 85,69 & 6,5 & То же & $\begin{array}{c}\text { Парагенезис с кар- } \\
\text { наллитом }\end{array}$ \\
\hline 10 & 1204 & 44,8 & 92,4 & 5,2 & То же & То же \\
\hline 13 & 1204,5 & 25 & 90 & Не обнаружено & То же & То же \\
\hline 10 & 1204,5 & 33,31 & 103,32 & То же & То же & То же \\
\hline 2 & 1207,5 & 29,39 & 102,14 & То же & То же & Сильвин красный \\
\hline 2 & 1209 & 43,3 & 87,1 & 7,6 & То же & - \\
\hline 2 & 1210 & 33,17 & 85,21 & Не обнаружено & То же & - \\
\hline 10 & 1212,3 & 29,7 & 83,0 & То же & 13,11 & - \\
\hline 2 & 1212,7 & 33,2 & 89 & 5,9 & Не обнаружено & - \\
\hline 10 & 1216,3 & 31,1 & 92,2 & Не обнаружено & 15,0 & - \\
\hline 10 & 1221,4 & 49,72 & 101,7 & То же & Не обнаружено & - \\
\hline 2 & 1222 & 19,2 & 106,8 & 25,84 & То же & - \\
\hline 2 & 1223,2 & 56,64 & 102,23 & Не обнаружено & То же & Сильвин красный \\
\hline 2 & 1227,4 & 36,1 & 74 & 8,4 & То же & - \\
\hline 2 & 1228 & 20,5 & 89,5 & 7,5 & То же & - \\
\hline 2 & 1234,5 & 20 & 110,2 & Следы & То же & - \\
\hline 2 & 1240 & 30,5 & 108,4 & Не обнаружено & То же & - \\
\hline 2 & 1250 & 24,2 & 48,6 & 6,7 & Нет & - \\
\hline 2 & 1258 & 22,8 & 52,3 & 6,1 & Не обнаружено & - \\
\hline 2 & 1271 & 22,3 & 35,8 & 10,2 & То же & - \\
\hline 7 & 1305 & 22,5 & 99,4 & 3,1 & То же & - \\
\hline 7 & 1317 & 34,2 & 78,0 & 6,5 & То же & - \\
\hline 7 & 1320 & 22,8 & 85,6 & 8,9 & То же & - \\
\hline 7 & 1325 & 19,7 & 91,2 & Следы & То же & - \\
\hline
\end{tabular}


Состав растворов включений в перекристаллизованном галите

\begin{tabular}{|c|c|c|c|c|c|c|c|}
\hline \multirow{2}{*}{$\begin{array}{c}\text { № сква- } \\
\text { жины }\end{array}$} & $\begin{array}{c}\text { Глубина, } \\
\text { м }\end{array}$ & \multicolumn{5}{|c|}{ Средние содержания, г/л } & \multicolumn{2}{c|}{$\mathrm{Br} \cdot 10^{3} / \mathrm{Cl}$} \\
\cline { 6 - 8 } & & $\mathrm{K}^{+}$ & $\mathrm{Mg}^{2+}$ & $\mathrm{SO}_{4}^{2-}$ & $\mathrm{Ca}^{2+}$ & $\begin{array}{c}\text { В жидкой } \\
\text { фазе }\end{array}$ & $\begin{array}{c}\text { В твердой } \\
\text { фазе }\end{array}$ \\
\hline 3 & 1072,9 & 8,5 & 88,7 & Не обнаружено & 2,8 & Не определялось & Не определялось \\
\hline 4 & 1085 & 7,9 & 91,0 & То же & 1,1 & То же & То же \\
\hline 6 & 1051,8 & 7,6 & 92,4 & То же & - & То же & То же \\
\hline 10 & 1207,3 & 34,8 & Не определялось & То же & 40,3 & То же & То же \\
\hline 10 & 1212,3 & 30,0 & 82,7 & То же & 13,11 & То же & То же \\
\hline 13 & 932,2 & 34,0 & Не определялось & Нет & 81,67 & То же & То же \\
\hline 2 & 958,8 & 6,64 & 5,49 & Следы & 28 & 7,85 & 0,11 \\
\hline 2 & 993 & 14,0 & 13,76 & 0,81 & 6,5 & 12,49 & 0,1 \\
\hline 2 & 1047,1 & 7,05 & 22,76 & 4,25 & 0,9 & 5,07 & 0,08 \\
\hline 2 & 1059,6 & 19,2 & 21,67 & 15,7 & 79,14 & 18,4 & 0,11 \\
\hline 2 & 1242 & 51,2 & 35,16 & 0,5 & 2,79 & 20,32 & 0,12 \\
\hline 2 & 1252 & 43,7 & 38,81 & 6,1 & 2,63 & 10,96 & 0,09 \\
\hline 2 & 1264 & 15,8 & 12.11 & 10,7 & 0,62 & 15,53 & 0,1 \\
\hline 2 & 1270 & 15,0 & 52,0 & 2,1 & Не обнаружено & Не определялось & Не определялось \\
\hline 3 & 1090,8 & 11,0 & 34,4 & Не обнаружено & 30,0 & То же & То же \\
\hline 4 & 1086,8 & 5,3 & 22,8 & То же & 27,6 & То же & То же \\
\hline
\end{tabular}

Перекристаллизация галита привела в данных интервалах к нарушению типичной седиментационной ритмичности каменной соли. На существенную роль перекристаллизованного галита здесь (где реликты седиментационного галита имеют концентрацию рапы включений на уровне эпсомитовой стадии) указывают также существенно пониженные значения бром-хлорного отношения, составляющие 0,04-0,07 [2, 3]. Это заметно ниже тех значений, которые характерны для начальных стадий садки галита $(0,09-0,1)$.

Сохранность первичных структур галита и элементарной ритмичности каменной соли возрастает в восточном направлении, в сторону скв. 6, и на север, в направлении скв. 2. В западном направлении от скв. 6 к скв. 4 происходит возрастание степени переработанности галитовой зоны. Вопрос об источниках поступления хлориднокальциевых растворов, приведших к перекристаллизации значительной части галогенного разреза погожской ритмопачки не решается однозначно. Вероятно, их можно связывать с бортом Преддонецкого прогиба, так как максимум изменений приурочен именно к этой структурной зоне. Здесь же отмечаются вертикальные трещинки с пленками углеводородов, секущие ангидритовые пласты и каменную соль. Они фиксируют миграцию флюидов и растворов из подсолевых отложений. Здесь, впрочем, возможно и латеральное движение рассолов. Именно с такими источниками растворов можно связывать и наблюдающиеся в надсолевых ангидрит-доломитовых породах, вскрытых в скв. 2, 3, 4, 5 и 6, повышенные концентрации, стронция и бора, которые связаны с минералами бора (колеманит, сульфоборит, витчит, ашарит и др.), стронция (целестин) и бария (барит), уста- новленными в нерастворимых остатках солей и в шлифах Н.М.Седлецкой и для части интервалов - О.П.Гончаренко $[4,1]$. Нами эти результаты подтверждены для разрезов скв. 13 и 10, в которых борная и стронциевая минерализация установлена в продуктивном пласте, в каменной соли, его перекрывающей, и в сульфатно-карбонатных пластах, находящихся на гипсометрическом уровне, близком к доломит-магнезитовому пласту скв. 3 .

Влияние растворов, за счет которых происходила перекристаллизация галитовой зоны, сказывалось и на породах калиеносного интервала. Высокая концентрация поровых растворов, присутствующих здесь, воспрепятствовала изменению минерального состава «продуктивного» пласта, хотя, возможно, с этими растворами связано появление в сильвините гнезд и линз шпатового сильвина (скв. 3), а также, вероятно, стала причиной разложения карналлита и образования красного сильвина с пониженным содержанием брома.

Образование каменной соли вышележащей ритмопачки - антиповской (гл. 1173,6-1037,5 м, см. рис. 1) начиналось при концентрации рапы на уровне начала галитовой стадии сгущения. В то же время степень метаморфизации рапы была весьма высокой. Соответствующие этому пониженные концентрации ионов сульфата в рапе (см. рис. 1, табл.1) можно связывать с существенной ролью терригенно-карбонатных составляющих. Средние части галитовой зоны (каменная соль с примесью карналлита и кизерита) характеризовались высокой концентрацией рапы $\left(\mathrm{K}^{+}-30 ; \mathrm{Mg}^{2+}-50-60\right.$; $\mathrm{SO}_{4}^{2}-24$ г/л), причем соотношение калия и магния свидетельствует о присутствии растворов, отвечающих седиментационному растворению и 
замещению калийных солей (гл. 1061,5 в скв. 2, см. табл. 1).

Образование галогенных отложений третьей галитовой зоны началось из рапы хлориднокальциевого состава. Формирование средней и верхних частей этой зоны шло уже из рапы сульфатно-магниевого типа (см. рис. 1, табл. 1). Такая особенность галогенной седиментации, как показывают наши исследования [5, 6], характерна лишь для краевых частей солеродного бассейна. Здесь полуизолированные участки (бассейнысателлиты) могли временно терять связь с основной акваторией бассейна, а поверхностный сток, определявший количество поступающего в них кальция, на отдельных стадиях процесса мог превалировать над существенно сокращенным поступлением сгущенных океанических вод сульфатно-магниевого состава. Диагенетические преобразования солей в третьей галитовой зоне весьма существенны. Они заключаются, прежде всего, в появлении перекристаллизованного галита, образовавшегося при очень высокой концентрации хлористого кальция в растворе $\left(\mathrm{Ca}^{2+}\right.$ до 60-80 г/л).

Условия формирования карналлитгалитовых пород и сильвинитов. Признаками высокой концентрации рапы, как уже отмечено выше, является появление в «перистом» галите минералов-узников. Для первичноседиментационного галита, не претерпевшего существенного повышения температуры на стадиях катагенеза, таким является минералузник карналлит. Почти одновременно, но чаще несколько позже, в каменной соли появляются гнезда карналлита. Образование этих интервалов каменной соли происходит при повышенных температурах (определялось методом гомогенизации вакуолей включений в галите). Для большинства пермских солеродных бассейнов мира эти температуры составляют $60-65^{\circ} \mathrm{C}$, а иногда и более [6, 7]. Но на стадии опреснения рапы они могут быть несколько меньшими. В связи с этим обращает на себя внимание то, что породы, вмещающие сильвиниты Гремячинского месторождения, формировались при несколько пониженных температурах $-45-50^{\circ} \mathrm{C}$.

Следует заметить, что появление вкрапленности карналлита в каменной соли, подстилающей калиеносные интервалы, характерно для всех изученных нами калиеносных разрезов Прикаспия. Связано это, вероятнее всего, с проникновением концентрированных растворов солеродного бассейна в неполностью консолидированный осадок каменной соли. Но, с другой стороны, галит-карналлитовые породы со значительной концентрацией карналлита являются закономерным элементом отложений на калийной стадии галогенеза. Так, в скв. 10 они подстилают сильвиниты. Обоснованием их первичного генезиса является то, что «перистый» галит, являющийся парагенным карналлиту, содержит включения с концентрацией рапы на уровне карналлитовой стадии (см. табл. 1), т.е. является эвтоническим. Отметим, что такое соотношение между карналлитом и сильвином характерно для отложений стадии опреснения, когда наблюдается «перевернутая» последовательность солей в разрезе. Это, например, известно для верхних элементов разреза антиповской и погожской ритмопачек Приволжской моноклинали и северо-западной части обрамления Прикаспийской впадины $[6,8]$ и для сложных циклов галогенеза, выделенных нами, когда сгущение рапы может сменяться временным опреснением и затем - новым сгущением. Видимо с последним случаем мы имеем дело на Гремячинском месторождении, где в скв. 6 карналлитовый пласт находится между двумя сильвинитовыми [1].

Условия образования карналлита. Карналлит в карналлитовых и карналлит-галитовых породах в большинстве случаев является первичноседиментационным. На это указывают результаты определения содержаний в данных породах брома и рубидия, расчета бром-хлорного и рубидийкалиевого отношения и более всего - состав рапы включений в галите (табл. 1, табл. 3). Вариации величин таких отношений в солях установлены работами М.Г.Валяшко и др. [9] и использованы для оценки условий образования солей Гремячинского месторождения [1]. Но не меньшую эффективность здесь имеют методы термобарогеохимии.

Таблица 3

Содержание рубидия в карналлит-галитовых породах Гремячинского месторождения (в расчете на чистый минерал) [9]

\begin{tabular}{|c|c|c|}
\hline № скважины & Глубина, м & $\mathrm{Rb}$, вес. $\%$ \\
\hline 2 & 1227,5 & 0,015 \\
\hline 2 & 1230,2 & 0,017 \\
\hline 2 & 1233,4 & 0,016 \\
\hline 3 & 1076,5 & 0,018 \\
\hline 6 & 1022,0 & 0,015 \\
\hline 6 & 1024,0 & 0,014 \\
\hline 6 & 1050 & 0,016 \\
\hline 6 & 1051,0 & 0,017 \\
\hline
\end{tabular}

Примечание. Анализы методом фотометрии пламени выполнены в НИИ Геологии СГУ (ныне отдел геологии НИИЕН СГУ), аналитик И.П.Гудошникова.

Определение состава рапы включений в галите, парагенном карналлиту, в образцах из разрезов скв. 2-6, 10, 13 (см. табл. 1) показывают, что концентрация основных компонентов в ней соответствует карналлитовой стадии $(\mathrm{K}+-18-25$ г/л, Mg - 90-115г/л). Бромхлорное отношение в галите из этих пород может изменяться в пределах 0,6-1,1, а в самом карналлите - от 5,25 до 9,3 [9]. Как показано [1], содержание рубидия в карналлите уменьшается по мере его 
кристаллизации от начальных к заключительным фазам его садки. Приведенные в табл. 4 данные подтверждают, что мы имеем дело с первичными карналлитами. Это не исключает присутствия на месторождении вторичного карналлита. Он устанавливался в породах стадии опреснения погожской ритмопачки, в отложениях относимых к антиповской ритмопачке в скв. $2[5,1]$. В этом случае даже сам состав пород (ангидрит-галит, при большей роли первого) позволяет предполагать его вторичный генезис.

Таблица 4

Средние содержания рубидия в молочно-белом сильвине Гремячинского месторождения

\begin{tabular}{|c|c|c|}
\hline № скважины & Глубина, м & $\begin{array}{c}\text { Содержание } \\
\text { рубидия, вес. \% }\end{array}$ \\
\hline 2 & 1207,5 & 0,005 \\
\hline 2 & 1209 & 0,006 \\
\hline 2 & 1211,5 & 0,008 \\
\hline 3 & 1057,8 & 0,002 \\
\hline 3 & 1060,8 & 0,003 \\
\hline 3 & 1064,3 & 0,003 \\
\hline 3 & 1070,1 & 0,002 \\
\hline 6 & 1022,6 & 0,0015 \\
\hline 6 & 1035,7 & 0,002 \\
\hline 6 & 1039 & 0,003 \\
\hline 6 & 1046,3 & 0,004 \\
\hline 6 & 1048,6 & 0,003 \\
\hline 7 & 1296,8 & 0,005 \\
\hline 7 & 1299,7 & 0,003 \\
\hline 7 & 1301,6 & 0,002 \\
\hline
\end{tabular}

Условия образования сильвина. Для этого минерала чисто седиментационные разности, адекватные «перистому» галиту, в ископаемых солях устанавливаются обычно лишь предположительно. В то же время многие исследователи отмечают в некоторых разностях сильвина присутствие первично седиментационных признаков. Таковыми являются, например, ритмично- зональная структура, определенные пределы содержаний брома, рубидия, величин отношений $\mathrm{Br} \cdot 10^{3} / \mathrm{Cl}$ и $\mathrm{K} / \mathrm{Rb}$ [9], состава растворов включений $[2,3]$.

Но обычно молочно-белый и розовый сильвин содержит газово-жидкие вакуоли (газа не более 1-3\%), жидкость в которых находится под значительным давлением. Эти признаки говорят о диагенетическом генезисе минерала. Давление в десятки атмосфер характерно и для чисто газовых вакуолей.

Ниже рассматриваются условия образования молочно-белого, розового и красного (прозрачного) сильвина из слоистых сильвин-галитовых пород и массивных сильвинитов Гремячинского месторождения. Рапа солеродного бассейна при ее прогрессирующем сгущении достигает силь- винитовой стадии еще при отложении каменной соли. Однако концентрации $\mathrm{K}^{+}$, отвечающие данной стадии, встречены в рапе включений в галите на латеральном продолжении калиеносных горизонтов и в зоне опреснения. В «перистом» галите и галите высаливания, наблюдающихся в виде отдельных кристаллов или прослоев в пластах калийно-магниевых пород, содержание этого компонента тоже отвечает сильвинитовой стадии. Безусловно, высокие концентрации $\mathrm{K}^{+}$и $\mathrm{Mg}^{2+}$ фиксируются в газово-жидких или трехфазовых включениях в сильвине. Практически для всех разностей эвтонического галита и вкрапленности сильвина, с признаками раннедиагенетического происхождения, содержание этих компонентов в целом соответствуют сильвинитовой стадии сгущения современной океанической воды $(\mathrm{COB})-$ - $\mathrm{K}^{+}-33,8$ г/л, $\mathrm{Mg}^{2+}-75,7$ г/л, иногда превышая данные значения. В то же время во всех без исключения образцах сильвина из сплошных сильвинитовых горизонтов, в рапе включений, количество ионов калия выше, чем для современной сгущенной океанической воды на сильвинитовой стадии на 15-17 г/л, магния - на 5-10 г/л. По нашему мнению, такая аномалия обусловливается периодическим растворением новосадки сильвина при неустойчивом характере гидрохимического режима на переходе от галитовой стадии к калийной, с расслоением рапы и постепенным падением в ней роли хлористого натрия. И лишь при прекращении этих «колебаний» начинается обвальная донная садка сильвина. На подобную закономерность отложения сплошных калийных солей мы показывали и ранее $[5,6]$.

Итак, признаками первично-седиментационного сильвина являются высокие значения бромхлорного отношения ( $>0,4$ для галита, находящегося в парагенезисе с сильвином и 2,9-4,0 в самом сильвине), состав рапы включений (содержания калия в рапе включений больше 32 г/л), и редко встречающаяся зональная структура минерала (установленная на месторождении лишь в единичных образцах молочно-белого сильвина из скв. 2). Содержания рубидия в сильвине [9], могут изменяться от 0,0017 в начале его садки до 0,0030 - в конце. Определения, выполненные по образцам молочно-белого сильвина из скв. 2, 3, 6 и 7, показали близкие значения, соответствующие первично-седиментационным (см. табл. 4). Но для части образцов получены завышенные значения. Анализ результатов определения содержаний брома также показал на то, что большая часть образцов молочно-белого сильвина оказались первичными (табл. 5).

Сильвин кристаллизовавшийся из рапы бассейна, в которой ранее произошло растворение карналлита. Эта разность сильвина характеризуется пониженным содержанием рубидия (табл. 6, рис. 3) и повышенным содержанием брома и бромхлорных отношений (табл. 7, рис. 4). Но для выводов о генезисе 
Таблица 5

Средние содержания брома и величина бромхлорного отношения в молочно-белом сильвине Гремячинского месторождения

\begin{tabular}{|c|c|c|c|}
\hline № скважины & Интервал, м & Содержание $\mathrm{Br}$, вес. \% & Пределы колебаний $\mathrm{Br} / \mathrm{Cl} \mathrm{x10}{ }^{-4}$ \\
\hline 2 & $1207-1216$ & 0,086 & $1,32-2,14$ \\
\hline 3 & $1057,3-1072,5$ & 0,140 & $2,45-3,48$ \\
\hline 6 & $1020-1050$ & 0,105 & $1,85-2,95$ \\
\hline 7 & $1296,3-1303,2$ & 0,135 & $2,59-3,05$ \\
\hline
\end{tabular}

Содержание рубидия в сильвинитах с красным сильвином

Таблица 6

\begin{tabular}{|c|c|c|c|c|}
\hline \multirow{2}{*}{ № скважины } & \multirow{2}{*}{ Глубина, м } & Содержание Rb, вес. \% & \multicolumn{2}{|c|}{ Содержание, \% } \\
\cline { 3 - 5 } & & & $\mathrm{NaCl}$ & $\mathrm{KCl}$ \\
\hline 2 & 1200,2 & 0,0092 & 51,48 & 48,52 \\
\hline 2 & 1203,7 & 0,01 & 50,75 & 49,25 \\
\hline 2 & 1206,3 & 0,012 & 27,85 & 72,15 \\
\hline 2 & 1223,6 & 0,013 & 44,6 & 55,4 \\
\hline 2 & 1224,9 & 0,04 & 43,7 & 56,3 \\
\hline 2 & 1226,5 & 0,008 & 99,85 & 0,25 \\
\hline 3 & 1053 & 0,017 & 27 & 72,6 \\
\hline 3 & 1053,2 & 0,01 & 52,14 & 47,76 \\
\hline 3 & 1074,5 & 0,02 & 20,8 & 79,2 \\
\hline 4 & 1035,5 & 0,05 & 28,98 & 71,02 \\
\hline 4 & 1036,7 & 0,012 & 64,03 & 35,97 \\
\hline 6 & 1008,5 & 0,007 & 56,4 & 43,6 \\
\hline 6 & 1012,3 & 0,0085 & 37,3 & 62,7 \\
\hline
\end{tabular}

Таблица 7

Содержание брома и величина бромхлорного отношения в красном сильвине месторождения в пересчете на чистый минерал

\begin{tabular}{|c|c|c|c|}
\hline № скважины & Интервал, м & Br- вес. $\%$ & $\mathrm{Br} \cdot 10^{3} / \mathrm{Cl}$ \\
\hline 2С & $1199,4-1201,4$ & 0,049 & 1,1 \\
\hline То же & $1201,4-1206$ & 0,072 & 1,49 \\
\hline То же & $1206-1207$ & 0,095 & 1,95 \\
\hline То же & $1226-1226,5$ & 0,057 & 1,2 \\
\hline То же & $1226,5-1231$ & 0,05 & 1,06 \\
\hline 3С & $1046-1047,3$ & 0,075 & 1,5 \\
\hline То же & $1047,3-1054,4$ & 0,09 & 1,85 \\
\hline То же & $1054,4-1057,3$ & 0,11 & 2,38 \\
\hline То же & $1072,5-1074,5$ & 0,1 & 2,1 \\
\hline 5С & $1004-1011,8$ & 0,077 & 1,57 \\
\hline То же & $1011,8-1016$ & 0,07 & 1,53 \\
\hline 6 С & $1006-1007$ & 0,04 & 0,85 \\
\hline То же & $1007-1009$ & 0,094 & 1,76 \\
\hline То же & $1009-1011$ & 0,063 & 1,3 \\
\hline То же & $1014-1016,2$ & 0,071 & 1,43 \\
\hline То же & $1025,2-1028$ & 0,095 & 1,99 \\
\hline То же & $1028-1029$ & 0,11 & 2,28 \\
\hline То же & $1029-1031,5$ & 0,065 & 1,36 \\
\hline То же & $1052-1055,5$ & 0,12 & 2,53 \\
\hline То же & $1057,5-1061,5$ & 0,12 & 2,32 \\
\hline То же & $1061,5-1062,5$ & 0,081 & 1,59 \\
\hline То же & $1063,5-1064,2$ & 0,066 & 1,41 \\
\hline 7 С & $1295-1296,3$ & 0,11 & 2,25 \\
\hline То же & $1298,5-1299,5$ & 0,09 & 1,93 \\
\hline
\end{tabular}

Примечание. Содержание брома в сильвинитах определялось в лаборатории Волгоградской ГРЭ. 


$$
\text { Rb, Bec.\% }
$$

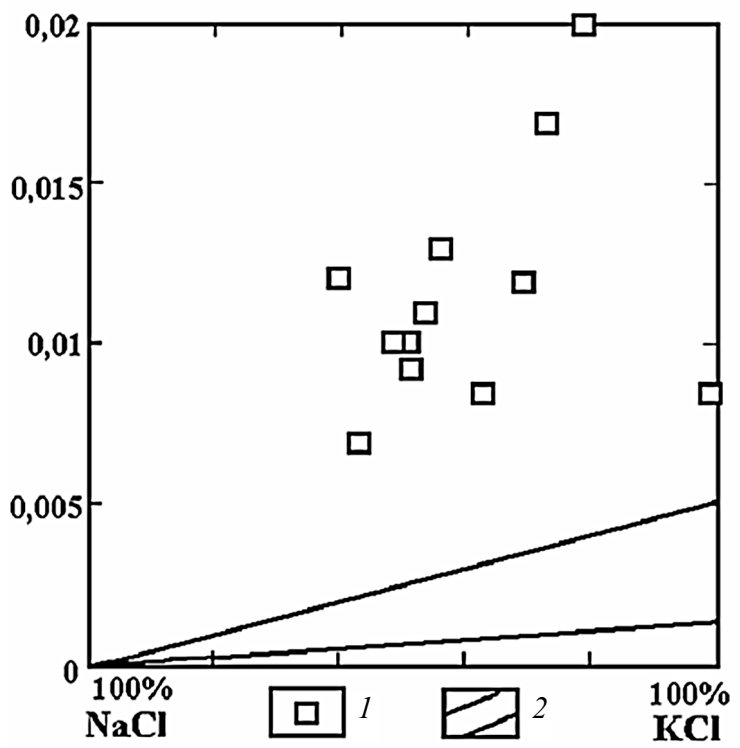

Рис. 3. Содержание рубидия в сильвин-галитовых породах с красным сильвином на шкале нормальных величин этого отношения: 1 - фигуративные точки, соответствующие данным табл. 6; 2 - поле седиментационных значений содержаний рубидия в сильвингалитовых породах

сильвина определяющая роль принадлежит методам термобарогеохимии: составы включений в этой разности сильвина и парагенном с ним галите отличаются высоким содержание магния (до 95-115 г/л), при практически полном отсутствии сульфата и кальция (см. табл. 1). Важным, по нашему мнению, является анализ взаимоотношения этого минерала с гидроокислами железа, являющимися постоянным элементом галогенной седиментации. Если гидроокислы железа, пластинки и иголки гематита более или менее равномерно распределены в сильвине, определяя его розовый цвет, то более вероятен первично-седиментационный его генезис. В то же время если гидроокислы железа лишь в виде обрывков каемок и лент обрамляют кристаллы сильвина, а также скопления ангидрита, мелкие кристаллы галита высаливания, то можно с большей уверенностью считать его вторичным по карналлиту. Судя по приведенным выше результатам определений брома и рубидия в красном сильвине Гремячинского месторождения его с полным основанием можно считать вторичным.

Сильвин может кристаллизоваться и при постседиментационном замещении карналлита уже в условиях раннего и даже позднего диагенеза. В этом случае все геохимические показатели, устанавливаемые при его анализе, будут также иметь характеристики карналлита: пониженное содержание рубидия (см. табл. 6, рис.3), повышенные бромхлорные отношения (см.

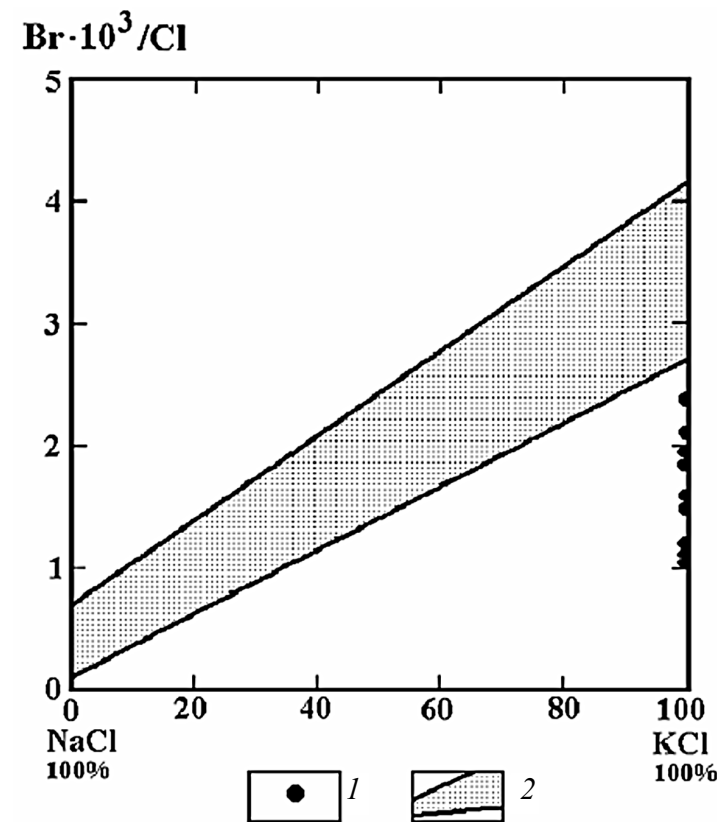

Рис. 4. Положение фигуративных точек величин бромхлорного отношения в красном сильвините Гремячинского месторождения, пересчитанных на чистый сильвин, на шкале «нормальных» величин этого отношения [9]: 1 фигуративные точки, соответствующие данным табл. 7; 2 - поле «нормальных» (седиментационных) величин бромхлорного отношения

табл. 7, рис. 4) - и состав растворов включений в седиментационном галите, сопровождающем его, соответствующий карналлитовой стадии галогенеза. При этом возможно даже существенное расхождение в составе включений рапы в сильвине и галите. И самое существенное - в его структуре не будет признаков седиментации в бассейне.

Диагенетические преобразования сильвина происходили при температурах $65-79^{\circ} \mathrm{C}$ (по данным гомогенизации). Незначительные скопления перекристаллизованных разностей молочно-белого сильвина встречены нами только в разрезе калиеносных интервалов скв. 2 и 3. Они характеризуются крупнокристаллическим строением и имеют сходство с прозрачным шпатовым сильвином Эльтонского месторождения и пестрым сильвинитом Верхнекамского месторождения. В таких разностях сильвина встречаются газовые вакуоли, имеющие высокое давление и мелкие кристаллики синего галита. Растворы включений данной разности сильвина отличаются высокими содержаниями ионов калия (40-42 г/л) и невысокими, для сильвинитовой стадии, содержаниями магния (70 г/л). Растворы включений в них находятся под давлением около 1,5 мПа и насыщены газами. Все это говорит о том, что указанный минерал образовался при позднедиагенетической перекристаллизации тех разностей сильвина, генезис которых мы определяли как раннедиагенетический. 
Подводя итог рассмотрению условий формирования сильвинитов и сильвин-галитовых пород Гремячинского месторождения, можно отметить следующее. Из всех разностей сильвинитов, выделенных нами на месторождении (красный и оранжево-красный, молочнобелый и розовый, крупнокристаллический, молочно-белый, шпатовый), первичными, образовавшимися путем кристаллизации из рапы, являются молочно-белый, розовый и красный. Но молочно-белый и розовый сильвин лишь завершает элементарный цикл накопления сильвинита, начинающийся с отложения красного сильвинита из рапы карналлитовой стадии и являющийся, видимо, десцендентной рапой, растворявшей на пути из основной части бассейна новосадку карналлита. В таком случае сильвиниты месторождения следует рассматривать как образования стадии опреснения погожского цикла, в полном объеме развитого в западной части впадины (район Эльтона). Шпатовый молочно-белый сильвин с вкрапленностью синего галита является перекристаллизованной разностью молочно-белого. Распространение двух основных разностей сильвина на месторождении определялось морфологий его дна.

\section{Заключение}

Изучение комплекса отложений кунгурского солеродного бассейна позволило обосновать следующее:

1. Калиеносные отложения формировались в солеродном бассейне и отражают его внутреннюю динамику и гидрохимию. Роль поверхностного стока на момент садки калийных солей была минимальной. Можно предполагать, что в это время заметная роль могла принадлежать хлориднокальциевым водам, которые, возможно, разгружались по разрывным нарушениям, ограничивавшим надвиговую структуру на юге.

2. Галогенные отложения, перекрывающие продуктивную толщу, формировались при весьма часто меняющихся динамике и гидрохимии вод бассейна, при возрастании роли поверхностного стока. Именно на этот интервал приходится максимальная деформация пород, связанная, по всей видимости, с горизонтальными движениями в районе надвига (на юге территории). По крайне мере, характер будинажа указанных пород позволяет предполагать преобладание деформаций сжатия, а не растяжения.

3. На месторождении, безусловно, первичными являются карналлит-галитовые породы (где карналлит не является вкрапленностью, а представляет равноценного члена парагенезиса, как и крупнокристаллический «перистый» галит с минералом-узником карналлитом в вакуолях включений). Но выделение красного сильвина как вторичного по карналлиту является также условностью, так как растворение и последую- щее отложение минералов происходило в рапе бассейна.

4. Скопления ангидрита, образующего линзы, тонкие слойки или рассеянную массу среди мелкокристаллических галита и сильвина, являются своеобразными аналогами базальных слоев элементарных ритмов. Но на Гремяченском участке солеродного бассейна нет доказательств опреснения бассейна на временной отрезок формирования таких слойков. Встречаются эти образования примерно через 30-50мм крупнокристаллических разностей сильвинита с пониженным содержанием ангидрита. По нашему мнению, данные слойки отражают внутреннюю гидродинамику бассейна, связанную с течениями гравитационного характера и перетоками между его различными участками.

5. На месторождении основными типами сильвинитов являются: а) среднекристаллические красные, красновато-оранжевые и пестрые; б) молочно-белые средне- и крупнокристаллические; в) крупнокристаллические шпатовые, перекристаллизованные. Молочно-белый и розовый сильвинит встречается в основном в кровельной части продуктивного пласта. Отличается несколько большими размерами кристаллов сильвина (3,5-4,5 и даже около 5 мм), а также большим идиоморфизмом кристаллов галита. Шпатовый перекристаллизованный сильвин по наличию вкрапленности синего галита, составу включений внешне похож на пестрый сильвинит Верхнекамского месторождения. Он отличается крупными размерами кристаллов сильвина (4-5,5 мм), несколько меньшим содержанием галита в породе, встречается намного реже остальных типов сильвинита и установлен нами лишь в нескольких интервалах в скв. 2 и 3.

\section{Библиографический список}

1. Свидзинский С.А., Музалевский М.М., Ковальский Ф.И. Гремячинское месторождение сильвинитов // Новые данные по геологии соленосных бассейнов Советского Союза. М., 1986, С. 204-219.

2. Московский Г.А., Гончаренко О.П., Макаров А.С. Интерпретация результатов определения макро- и микрокомпонентов в растворах включений и в твердой фазе минералов галогенных отложений // Геохимия. 1989. № 1. С. 61-67.

3. Московский Г.А., Гончаренко О.П. Основные черты геохимии кунгурского галогенеза в западной части Прикаспийской впадины (по включениям в минералах). Деп. в ВИНИТИ 16.11.89, 4072-В90. М., 1989. 198 с.

4. Гончаренко О.П. Бороносность пермского галогенной формации Прикаспийской впадины. Саратов, 2005. 96 с.

5. Московский Г.А. Исследования физико-химических условий седиментации кунгурских отложений западной части Прикаспийской синеклизы по включениям в минералах: Автореф. дис... канд. геол.-минерал. наук. М., 1983. $19 \mathrm{c}$. 
6. Московский Г.А. Пермский галогенез Прикаспия: Автореф. дис... д-ра геол.-минерал. наук. Воронеж, 2000. $36 \mathrm{c}$.

7. Петриченко О.И. Физико-химические условия осадкообразования в древних солеродных бассейнах. Киев, $1988,128 \mathrm{c}$.

8. Московский Г.А., Свидзинский С.А. Соотношение ритмопачек и циклов седиментации в галогенных разрезах Северного Прикаспия // Советская геология. 1989. № 5. C. 49-54.

9. Валяшко М.Г., Петрова И.С. Использование брома и рубидия в качестве геохимических индикаторов при оценке генезиса калийных солей // Бром в соляных отложениях и рассолах. М., 1976. С. 418-427.

УДК [626.34 : 551.435 .1$](470.44-25)$

\section{ЕСТЕСТВЕННАЯ И ИСКУССТВЕННАЯ ДРЕНАЖНЫЕ СЕТИ ТЕРРИТОРИИ САРАТОВА: СОВРЕМЕННОЕ СОСТОЯНИЕ И СООТНОШЕНИЕ}

\section{И.А. Яшков, Г.И. Худяков ${ }^{1}$, А.В. Иванов \\ Саратовский государственный университет, кафедра геоэкологии \\ E-mail: YashkovlA@mail.ru \\ ${ }^{1}$ кафедра геоморфологии и геоэкологии \\ E-mail: geomorph@sgu.ru}

В статье рассматриваются основные проблемы современного функционирования городской дренажной сети. Проведен анализ геоэкологического состояния отдельных участков городской эрозионной и ливневой систем. Предлагается ряд мер для оптимизации коэволюции естественной и искусственной дренажных сетей на примере территории Саратова.

Natural and Artificial Drainage Networks of Saratov: Modern State and Relation

\section{I.A. Yashkov, G.I. Khudyakov, A.V. Ivanov}

Problems of modern urban drainage network functioning have been considered. Analysis of geoecological state of separate regions of urban erosive and drawn systems has been carried out. An approach to the optimization of natural and artificial drainage networks has been suggested by the example of Saratov territory.

\section{Введение}

В настоящее время в условиях стремительного роста и усложнения урбанизированных территорий различные геоэкологические процессы, негативно влияющие на нормальное функционирование городских систем, приобретают прогрессирующий характер. Для территории Саратова такими главными негативными геоэкологическими эффектами являются подтопление и оползневые процессы. Среди основных причин, стимулирующих активизацию этих процессов в городе, можно назвать следующие:

1) геолого-геоморфологические (подъем уровня грунтовых вод, относительно слабая дренированность территории, подмыв берегов водохранилища и др.);

2) инженерно-технические (давление жилых, промышленных и транспортных систем и сооружений на литогенную основу города; за-

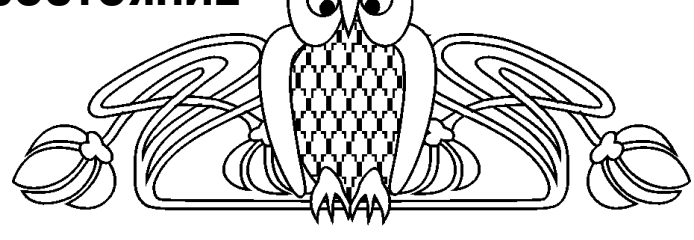

стройка жилыми и промышленными зданиями и сооружениями несогласно основным уклонам поверхности геоморфологических структур и соответственно поперек естественному стоку поверхностных и грунтовых вод; порывы водонесущих трубопроводных сетей и утечка бытовых, технических и канализационных вод в почвогрунты и др.).

Одним из основных элементов городской поверхностной структуры, обеспечивающих ее функционирование, являются естественная и искусственная дренажные сети - своего рода «кровеносная система» городского «организма». Под естественной дренажной сетью (ЕДС) будем понимать всю систему эрозионной сети на урбанизированной территории, включающей в себя долины рек, балок и оврагов и их более мелких, соподчиненных им, элементов: ложбин, промоин, рытвин. Искусственная дренажная сеть (ИДС) включает в себя городскую ливневую канализацию и дренажные сооружения.

В настоящее время в развитии урбанизированной системы Саратова наблюдаются определенные закономерности и процессы, которые сильно влияют на всю работу, выполняемую ЕДС и ИДС. По мере развития городской территории нагрузка на общую систему дренажных сетей постоянно растет. За последние два-три десятилетия в динамике развития дренажной сети происходят негативные процессы, связанные с естественным и антропогенным нивелированием городского рельефа, уничтожением эрозионной сети в результате застройки, засыпки техногенным материалом и замусоривания долин рек, оврагов и недостаточным строительством новых линий ливневых коллекторов и дренажей.

Предпосылкой выработки стратегии оптимизации функционирования ЕДС и ИДС городских территорий являются следующие комплексные геоэкологические и эколого-геологические исследования изучаемых объектов. 